\title{
Combined Hepatic and Renal Transplantation in Primary Hyperoxaluria Type I: Clinical Report of Nine Cases
}

\author{
RICHARD W. E. WATTS, M.D., D.Sc., Ph.D., F.R.C.P., F.R.S.C., STEPHEN H. MORGAN, M.B., \\ M.R.C.P., CHRISTOPHER J. DANPURE, Ph.D., PAUL PURKISS, M.Sc., M.R.S.C., Harrow, England, \\ ROYY. CALNE, M.S., F.R.C.S., F.R.S., KEITH ROLLES, F.R.C.S., Cambridge, England, LAURENCE R. I. \\ BAKER, M.D., F.R.C.P., MARTIN A. MANSELL, M.D., F.R.C.P., London, England, LYNWOOD H. SMITH, \\ M.D., Rochester, Minnesota, RoBERT M. MERION, M.D., MiCHAEL R. LUCEY, M.D., F.R.C.P.I., Ann \\ Arbor, Michigan
}

PURPOSE AND PATIENTS AND METHODS: The purpose of this article is to report the experience of three centers with combined hepatic and renal transplantation for pyridoxine-resistant primary hyperoxaluria type I (alanine:glyoxylate aminotransferase [EC 2.6.1.44] deficiency), with particular emphasis on the selection criteria and timing of the operation. Nine patients with this inherited disease were treated by combined hepatic and renal transplantation. The former replaces the enzyme-deficient organ while the latter replaces the functionally affected organ.

RESULTS: One patient with gross systemic oxalosis died in the immediate postoperative period and another died 8 weeks postoperatively of a generalized cytomegalovirus infection, having shown evidence of biochemical correction. One patient with particularly severe osteodystrophy at the time of the operation died 14 months postoperatively from renal failure due to progressive calcium oxalate nephrocalcinosis involving the transplanted kidney, plus thromboembolic disease. He also had very extensive systemic oxalosis. An additional patient with severe osteodystrophy died 9 months postoperatively. One patient developed hyper-rejection of the kidney and died later of gastrointestinal hemorrhage. The four long-term survivors (22 to 38 months) have remained asymptomatic from the standpoint of their renal disease, with resolution of any manifestations of systemic oxalosis that they

From the Clinical Research Centre (RWEW, SHM, CJD, PP), Harrow, England; Department of Surgery (RYC, KR), University of Cambridge, Cambridge, England; Department of Nephrology (LRIB), St. Bartholomews Hospital, London, England; St. Peters Hospital and Institute of Urology (MAM), London, England; Division of Nephrology (LHS), The Mayo Clinic, Rochester, Minnesota; and Departments of Internal Medicirre and Surgery (RMM, MRL), University of Michigan, Ann Arbor, Michigan.

Requests for reprints should be addressed to Richard W. E. Watts,

M.D., Wellington Hospital, Wellington Place, London, NW8 9LR, England.

Manuscript submitted May 23,1990, and accepted in revised form October 7, 1990 may have had. They are either employed or continuing their education.

CONCLUSIONS: A prolonged period of end-stage renal failure treated by dialysis regimens that are suitable for non-hyperoxaluric renal failure and extensive systemic oxalosis, particularly oxalotic osteodystrophy, are poor prognostic features. We propose that hepatic transplantation should be considered as definitive treatment before end-stage renal failure develops. This should be supplemented by renal transplantation with vigorous pre- and perioperative hemodialysis to deplete the body stores of oxalate. $\mathrm{Al}$ though some authorities would reserve hepatic transplantation for patients in whom renal transplantation has failed, we suggest that combined liver and kidney transplantation is appropriate in patients who have never had a renal graft. Furthermore, the time has come to consider hepatic transplantation before any irreversible renal damage has occurred in these patients.

$\mathbf{P}$ rimary hyperoxaluria type $\mathrm{I}(\mathrm{PHI})$ is an autosomal recessively inherited inborn error of metabolism [1] that is due to alanine:glyoxylate aminotransferase (AGT: EC 2.6.1.44) deficiency in the liver [2-4]. There is increased synthesis and excretion of oxalate and ylycolate with recurrent calcium oxalate urolithiasis and irreversible nephrocalcinosis, which cause fatal renal failure. Calcium oxalate is deposited in many tissues (oxalosis) when oxalate retention and oxalate over-production combine to produce greatly increased oxalate ion concentration in the tissue fluids generally. Except for the treatment of pyridoxine-responsive variants of the disease with pharmacologic doses of the vitamin $[5,6]$, there had been no reports of biochemical correction of the disease until Watts et al [7] reported a case treated by combined hepatic and renal transplantation (Patient 1 in this communication). Although 


\begin{tabular}{|c|c|c|c|c|c|c|c|}
\hline \multicolumn{8}{|c|}{$\begin{array}{l}\text { TABLE I } \\
\text { The Patients }\end{array}$} \\
\hline Patient & Sex & $\begin{array}{l}\text { Age at First } \\
\text { Symptoms } \\
\text { (years) }\end{array}$ & $\begin{array}{l}\text { Age at Onset of } \\
\text { First Episode } \\
\text { of End-Stage } \\
\text { Renal Failure } \\
\text { (years) }\end{array}$ & $\begin{array}{c}\text { Previous Kidney } \\
\text { Transplant }\end{array}$ & $\begin{array}{c}\text { Kidney Transplant } \\
\text { Survival }\end{array}$ & $\begin{array}{c}\text { Cause of Kidney } \\
\text { Transplant } \\
\text { Failure }\end{array}$ & Previous Reference \\
\hline 1 & $M$ & 7.5 & 17.5 & 1 cadaveric & 10 days & Oxalate deposition & $\begin{array}{l}\text { Patient } 2[41,42] \\
\text { Single case [7] } \\
\text { Patient NA [38] }\end{array}$ \\
\hline 2 & $M$ & 1.5 & 22 & $\begin{array}{l}1 \text { live related } \\
1 \text { cadaveric }\end{array}$ & $\begin{array}{l}5 \text { months } \\
1 \text { month }\end{array}$ & $\begin{array}{l}\text { Oxalate deposition } \\
\text { Acute rejection }\end{array}$ & $\begin{array}{l}\text { Patient GF [38] } \\
\text { Patient F [4] } \\
\text { Patient GF [38] }\end{array}$ \\
\hline 3 & $\mathrm{~F}$ & 7 & 19 & 0 & - & - & - \\
\hline 4 & $M$ & 6 & 19 & 1 cadaveric & 8 months & Oxalate deposition & Patient H [38] \\
\hline 5 & $M$ & 11 & 36 & 1 cadaveric. & 14 days & $\begin{array}{l}\text { Oxalate deposition } \\
\text { and rejection }\end{array}$ & [16] \\
\hline 6 & $M$ & 18 & 28 & 1 cadaveric & 11 months & Oxalate deposition & 一 \\
\hline 7 & $M$ & 8 & 15 & 0 & - & - & - \\
\hline $8^{*}$ & M & 19 & 23 & $\begin{array}{l}1 \text { cadaveric } \\
1 \text { live related }\end{array}$ & $\begin{array}{l}\text { Never functioned } \\
<1 \text { week }\end{array}$ & ?Cyclosporin toxicity & - \\
\hline $9^{*}$ & $M$ & 10 & 26 & 1 cadaveric & 21 months & Oxalate deposition & - \\
\hline
\end{tabular}

that patient died of a disseminated cytomegalovirus infection about 8 weeks after transplantation, the biochemical results encouraged further work by the same group, who were subsequently able to report a patient in whom combined liver and kidney transplantation led to near-normalization of plasma and urine metabolite levels and who was well and in regular employment 8 months postoperatively [8] (Patient 2 in this communication). This was a notable advance in the management of a previously untreatable disease and an example of the widening scope of liver transplantation as a means of enzyme replacement in the treatment of the inborn errors of metabolism. We now report experience with combined hepatic and renal transplantation for PHI from three centers with particular reference to the selection criteria and timing of the operation. We also discuss some aspects of pre- and perioperative management, the relative merits of a one- or two-stage operation, and evidence that the successfully treated patients gradually mobilize their systemic oxalate deposits.

\section{PATIENTS AND METHODS}

The case histories of the patients were all typical of PHI (Table I). All of these patients had had recurrent urinary stones and were in end-stage renal failure. In five patients, renal transplantation had failed, and one patient (Patient 4) had present- ed in end-stage oliguric renal failure 8 years before liver transplantation. All but one of the livers were completely, or almost completely (less than $2 \%$ ), lacking in AGT activity (Table II). However, one patient (Patient 7) had a significant residual activity of AGT (9\%). There is no evidence that severe chronic renal failure has any effect on hepatic AGT activity. In fact, a diagnosis of PHI has been excluded in three patients with end-stage renal disease by their completely normal liver AGT levels (Danpure, unpublished observations). Five patients had no detectable immunoreactive AGT protein and three had detectable but significantly reduced levels. $\mathrm{Pa}$ tient 4 had normal levels of immunoreactive AGT protein despite having almost no AGT enzyme activity (Table II).

\section{Methods}

The analytical methods were derived from the following references: urine and plasma oxalate [911]; urine and plasma glycolate [12]; glomerular filtration rate (GFR) by a standard isotopic EDTA- or DTPA-chelate technique, liver AGT (EC 2.6.1.44) and glutamate:glyoxylate aminotransferase (GGT; EC 2.6.1.4) enzyme activities [3]; and immunoreactive AGT protein [13]. The surgical procedures used are those described by Calne $[14,15]$, and consist of orthotopic grafting of the liver to the hepatic fossa with anatomic anastomoses of the vessels and renal 
transplantation to the right iliac fossa together with ureteric drainage into the bladder.

\section{RESULTS}

Table III shows the condition of the patients when they underwent transplanation and the outcome in each case. Patients 2, 4, 5, 6, and 7 all had good postoperative outcomes with satisfactory recovery of liver function and adequate residual renal function. Patient 6 underwent combined liver and kidney transplantation despite systemic manifestations of oxalosis that included congestive cardiomyopathy due to myocardial oxalosis (confirmed by myocardial biopsy), complete heart block, and peripheral neuropathy plus end-stage renal failure. $\mathrm{He}$ had been treated by continuous ambulatory peritoneal dialysis and one renal allograft for 18 months. Since combined transplantation, his cardiomyopathy has resolved. Patient 4, who had undergone chronic hemodialysis for 7 years preoperatively, presented in end-stage renal failure with very painful oxalotic osteodystrophy, which persisted and prevented normal activities. Postoperatively, he lost kidney function progressively because of calcium oxalate nephrocalcinosis in the grafted kidney and died 14 months later with extensive thromboembolic disease (multiple pulmonary infarcts, cerebrovascular disease, inferior vena cava obstruction) and heart failure. However, Patients 2, 5, 6, and 7 have been able to resume their regular employment. Patient 3 had been in end-stage renal failure for 5 years. This had been treated initially by continuous ambulatory peritoneal dialysis and subsequently by hemodialysis regimens suitable for non-hyperoxaluric renal failure. Neither of these regimens was sufficient to prevent very severe systemic oxalosis, which showed as gangrenous toes, right bundle branch block, arterial calcification, osteosclerosis, and synovitis. She became septicemic and died during the immediate postoperative period.

Patient 8 had very severe osteodystrophy. $\mathrm{He}$ sustained bilateral pathologic fractures of the femoral necks and effusions into his right knee about 3 months before the orthotopic liver transplantation. His postoperative course included cardiopulmonary complications, recurrent pleural effusions, a liver abscess, gastric ulcers, and generalized debility and wasting. He died 9 months after the liver transplantation.

Patient 9 made a good immediate recovery from the hepatic and renal transplantation. The kidney functioned well and removed about $13,000 \mathrm{mmol}$ of oxalate in 6 days. However, he developed hyperacute rejection of the grafted kidney on the eighth

\begin{tabular}{|c|c|c|c|c|}
\hline $\begin{array}{l}\text { TABLE II } \\
\text { Liver Enzy }\end{array}$ & Activities ( & ol - hour-1 & g protein -1 & \\
\hline Patient & AGT & GGT & AGT* & CRM \\
\hline Native liver & & & & \\
\hline 1 & 0.70 & 1.01 & 0.03 & - \\
\hline 2 & 0.42 & 0.58 & 0.04 & - \\
\hline 3 & 0.44 & 0.65 & 0.01 & - \\
\hline 4 & 0.54 & 0.69 & 0.08 & +++ \\
\hline 5 & 0.54 & 0.90 & & $+1-$ \\
\hline 6 & 0.51 & 0.68 & 0.06 & - \\
\hline 7 & 0.98 & 0.90 & 0.39 & + \\
\hline 8 & 0.62 & 0.87 & 0.05 & - \\
\hline 9 & 0.53 & 0.72 & 0.05 & $+1-$ \\
\hline $\begin{array}{l}\text { Donor IIver } \\
3\end{array}$ & 4.01 & 0.38 & 3.76 & +++ \\
\hline 6 & 6.26 & 0.82 & 5.72 & +++ \\
\hline Controls & & & & \\
\hline $\begin{array}{l}\text { Mean } \\
\text { Range }\end{array}$ & 5.00 & 0.65 & 4.50 & \\
\hline Number & & & & \\
\hline
\end{tabular}

AGT = alanine:glyoxylate aminotransferase; GTT = glutamate:glyoxylate aminotransferase: $C R M=$ immunologically cross-reacting $A G T(+++=$ normal, -- not detectable). $* A G T$ corrected for crossover [3] from GGT $\left(\mathrm{AGT}^{*}=\mathrm{AGT}-[\mathrm{GGT} \times 0.66]\right)$

$\dagger$ From [3].

postoperative day. The kidney was removed and hemodialysis was reinstituted. The liver continued to function well. His general condition, particularly the bone and joint pain, improved. However, he died of a massive gastrointestinal hemorrhage about 3 months postoperatively.

"High-resolution $\mathrm{x}$-ray powder diffraction analysis of bone and kidney tissue from Patients 8 and 9 yielded $x$-ray diffraction maxima for calcium oxalate monohydrate only. The widths of the diffraction maxima for the bone calcium oxalate were narrower than for most calcium oxalate stone patterns. This implies that the calcium oxalate crystals [were] highly crystallized" (Dr. Neil S. Mandel). In oxalotic osteodystrophy, calcium oxalate replaces the bone calcium phosphates, and its high crystallinity weakens the bones.

Figure 1 shows the long-term changes in the plasma oxalate concentration, the urinary oxalate excretion, and the GFR in two of the patients $(\mathrm{Pa}-$ tients 2 and 7) who have made good long-term recoveries and in Patient 4 who had advanced osteodystrophy when he received his transplant and who died after about 14 months. The changes in Patient 5 , who also had a good long-term outcome, were similar to those in Patients 2 and 7, with the plasma oxalate concentration decreasing toward normality over the course of several months and the urinary oxalate excretion values declining more slowly. The urinary glycolate values decreased immediately after the transplantation as shown in Table IV. The available data for Patient 6 are more limited. His highest recorded plasma oxalate concentration was $170 \mu \mathrm{mol} / \mathrm{L} 1$ month before transplantation and 100 


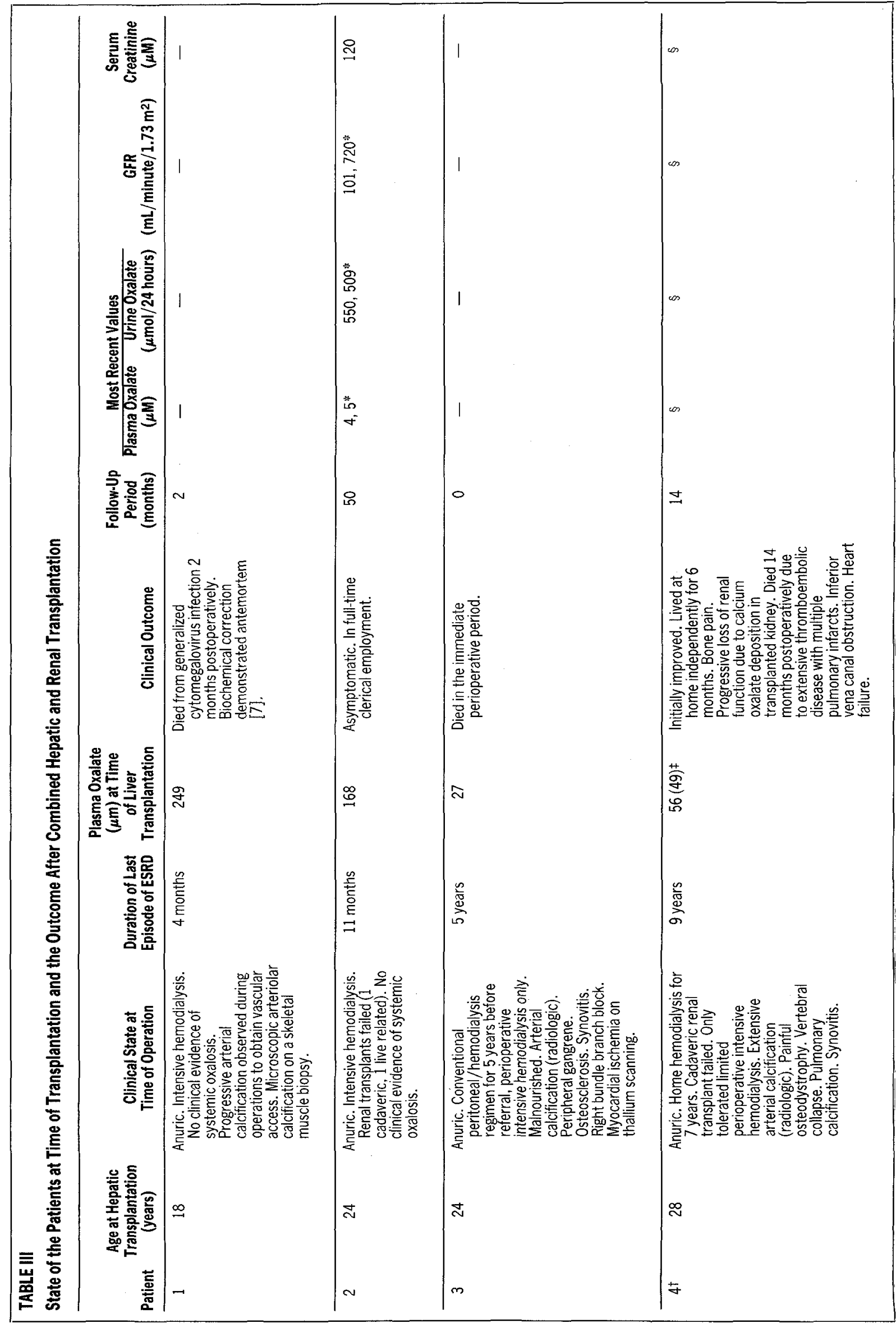




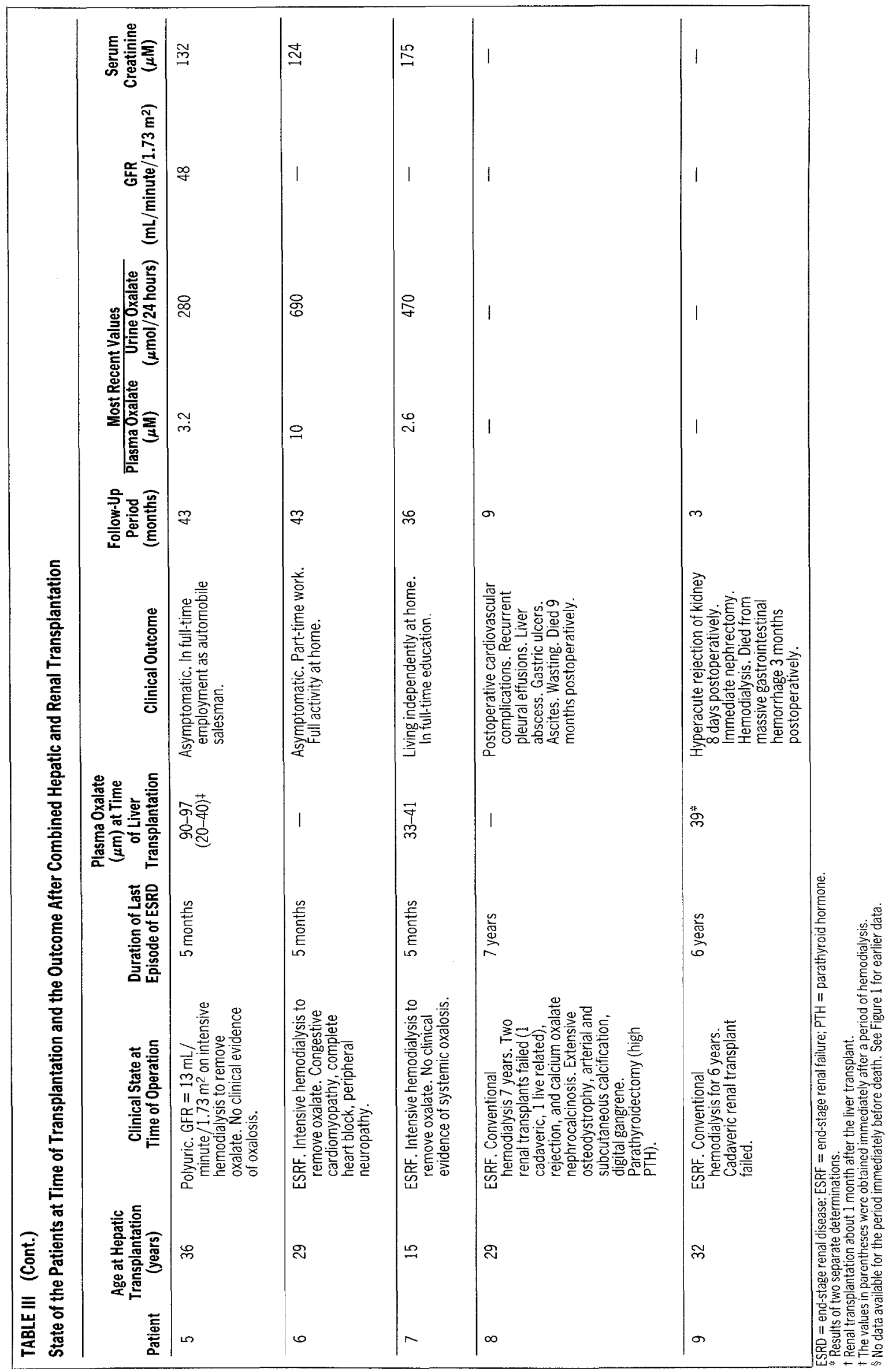



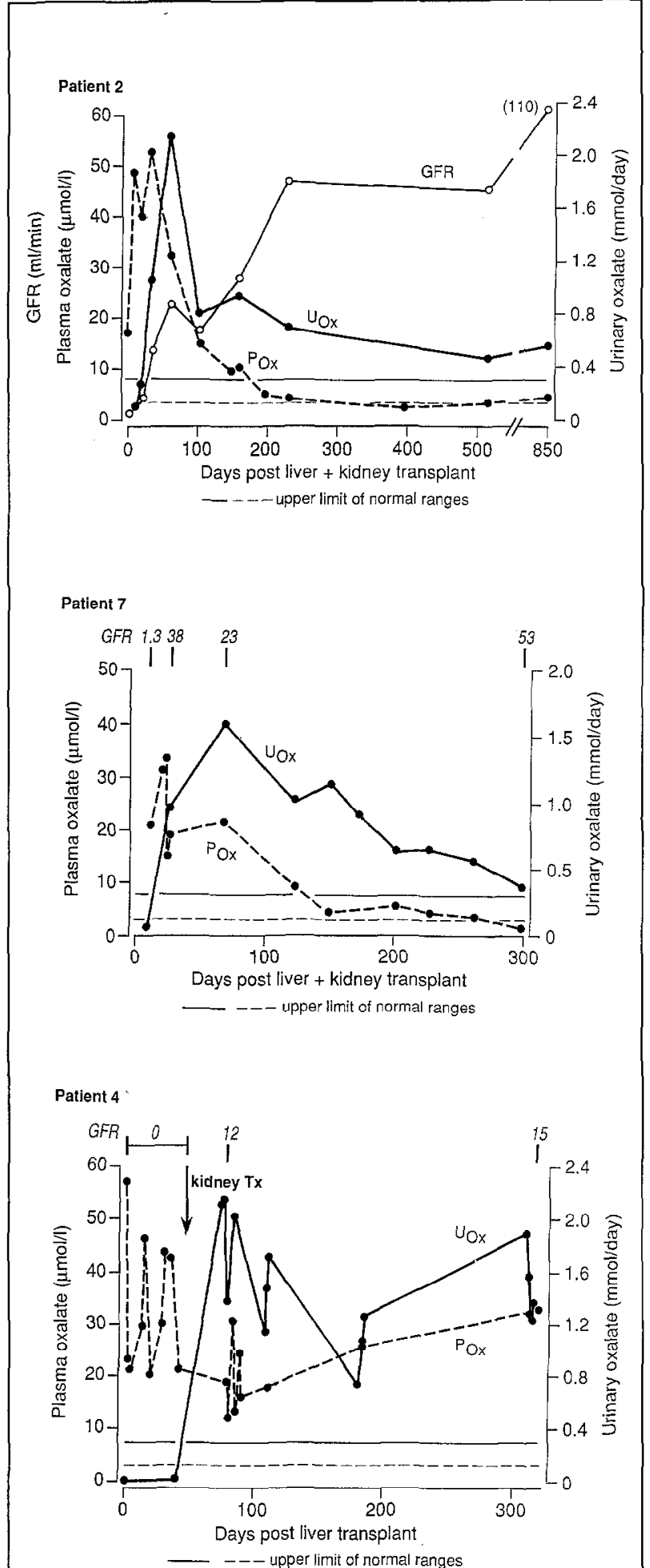

Figure 1. The short- and long-term changes in the urinary oxalate excretion $\left(\mathrm{U}_{\mathrm{OX}}\right)$, plasma oxalate concentration $\left(\mathrm{P}_{\mathrm{OX}}\right)$, and glomerular filtration rate (GFR) in Patients 2 and 7 who had good posloperalive recoveries and in Patient 4 who died about 14 months postoperatively. Horizontal lines - - and - . . - - show the upper limits of the reference ranges for $P_{D_{x}}$ and $U_{o x}$, respectively.

\section{TABLE IV}

Comparative Values for the Urinary Excretion of Oxalate and Glycolate Before and After Hepatorenal Transplantation (Patient 5)

\begin{tabular}{ccc}
\hline & \multicolumn{2}{c}{$\begin{array}{c}\text { Urinary Excretion } \\
\text { (mmol/24 hours) }\end{array}$} \\
\cline { 2 - 3 } & Oxalate & Glycolate \\
\hline Before transplant & 8.88 & 3.86 \\
\hline After transplant & & \\
Day 3 & 2.9 & 0.12 \\
5 & 3.0 & 0.32 \\
6 & 3.0 & 0.32 \\
9 & 2.7 & 0.36 \\
26 & 2.0 & 0.82 \\
54 & 1.1 & 0.46 \\
82 & 1.0 & 0.78 \\
98 & 0.6 & 0.5 \\
155 & 0.4 & 0.48 \\
191 & 0.5 & 0.54 \\
\hline
\end{tabular}

$\mu \mathrm{mol} / \mathrm{L}$ and $28 \mu \mathrm{mol} / \mathrm{L}$ immediately before and after hemodialysis, respectively, before the transplantation. Six months after transplantation, the plasma oxalate concentration and urinary oxalate excretion were $13 \mu \mathrm{mol} / \mathrm{L}$ and $2.9 \mathrm{mmol} / 24$ hours, respectively.

Some of the data for Patient 2 have been published previously [8]. Data on Patient 5 have also been presented in preliminary form [16].

\section{COMMENTS}

The development of cyclosporine for the control of graft rejection has encouraged organ transplantation as a means of enzyme replacement therapy. In PHI, liver transplantation provides the missing enzyme (AGT) in the normal cellular and subcellular locations. Because of the central role of the liver in intermediary metabolism, liver transplantation merits particular attention as a means of enzyme replacement for inborn errors of metabolism in which the metabolic lesion is specifically expressed in the liver. Hepatic failure, as in Wilson's disease [17] and tyrosinemia type I [18], has heretofore been the main indication for the operation in this field. However, there is an expanding range of inborn errors of metabolism in which liver transplantation is becoming the preferred method of treatment because the allograft either synthesizes a factor for export to another organ, (e.g., $\alpha_{1}$-antitrypsin deficiency) [19-21], or protects another organ from damage by a toxic metabolite as in the Crigler-Najjar syndrome [22]. Liver transplantation can correct multiple secondary metabolic derangements as in glycogen storage disease type I [23]. Starzl and colleagues $[20,21,24]$ have also successfully treated a child with familial hypercholes- 
terolemia by a combined liver and heart transplantation [25].

The data presented in this paper support and amplify our previous conclusion that liver transplantation is potentially curative in $\mathrm{PHI}[7,8]$. AGT is almost entirely liver-specific [26]. Therefore, transplantation of this organ should reintroduce nearly all of the body's requirement for the enzyme. Liver transplantation lowered the glycolate levels immediately, whereas plasma and urinary oxalate levels reverted toward normal much more slowly in our patients. The metabolic fluxes of glyoxylate, oxalate, and glycolate before and after liver transplantation are shown diagramatically in Figure 2. Glycolate does not form a highly insoluble calcium salt, so that once excessive synthesis is corrected, only the contents of the expanded soluble glycolate metabolic pool have to be excreted. Conversely, calcium oxalate is highly insoluble and is deposited in many tissues when oxalate retention due to advanced renal failure is added to oxalate overproduction. We interpret the more gradual decrease in the plasma and urine oxalate levels, with the urine levels lagging behind the plasma levels, to mobilization of the extrarenal oxalotic deposits. Cochat et al [27] have shown that if the liver is transplanted when renal function is still good and before there is any systemic oxalosis, the plasma oxalate also normalizes on the first postoperative day. The final extent to which calcium oxalate can be removed from the tissues remains to be assessed, but the results in Patient 6 show that cardiac oxalosis is potentially reversible. Better methods than those currently available for measuring the amount of oxalate in tissues in vivo are needed.

Patients with pyridoxine-resistant PHI who are treated by long-term hemodialysis or peritoneal dialysis die from the effects of their systemic oxalosis because treatment regimens that control the uremia are not sufficient to keep up with the rate of oxalate production, at least in the long term [28]. This situation is exemplified by Patients 3 and 4 in the present study. The only definitive treatment options, unless the patient is highly responsive to pyridoxine, are either renal transplantation, which replaces the damaged target organ but leaves it exposed to the risk of further stone formation and/or nephrocalcinosis, or liver transplantation or a combined liver and kidney transplant. The last of these both normalizes the rate of oxalate production by correcting the metabolic lesion and replaces the damaged target organ. The results of renal transplantation alone have usually been poor, if it has been performed when the patient was already in end-stage renal failure [29-32], although there have

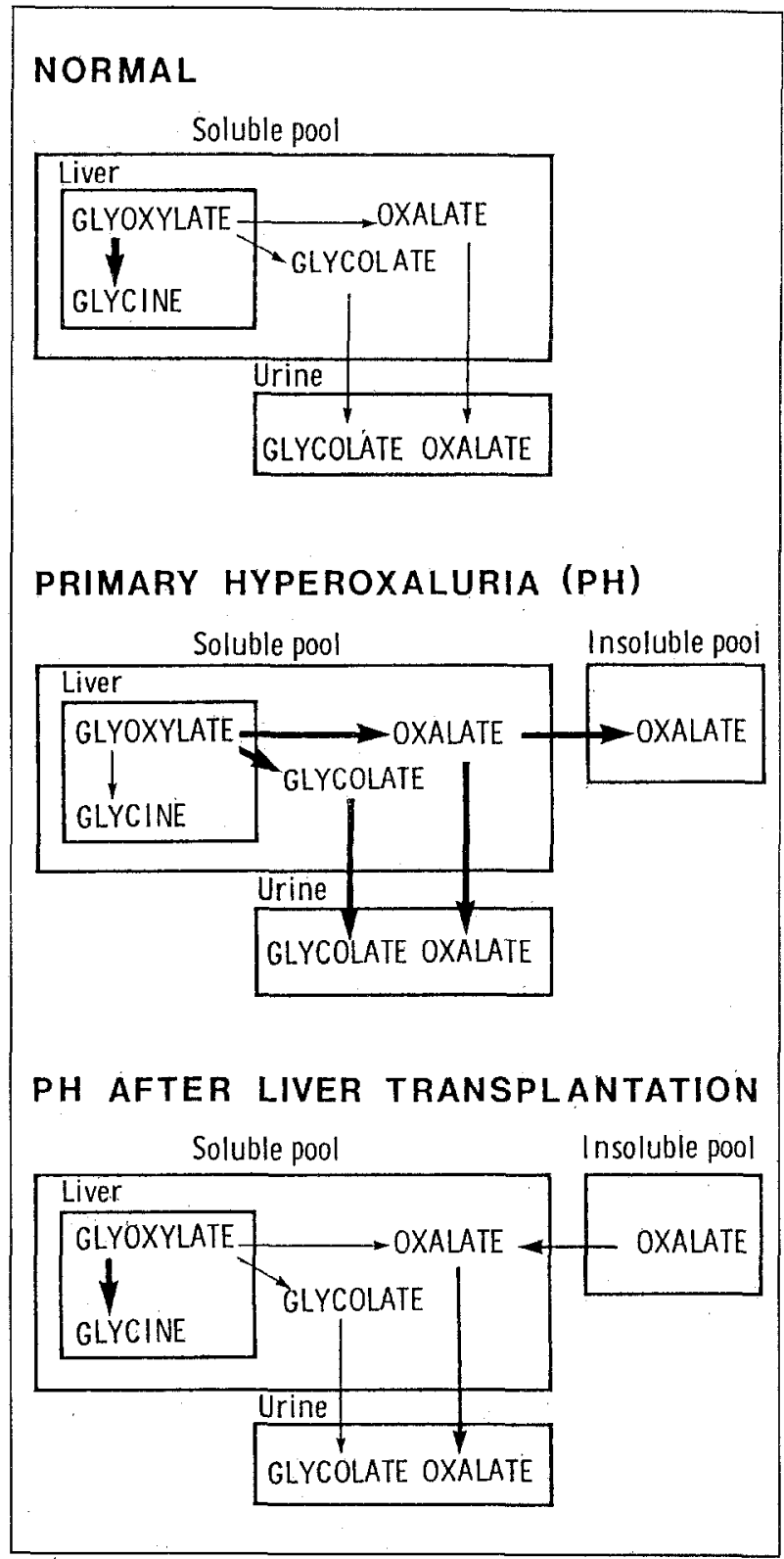

Figure 2. The metabolic fluxes of glyoxylate and its metabolic products in a normal subject and in a palient wilh PHI before and after liver transplantation. The thickness of the arrows represents the magnitude of the flux in the direction indicated. Note that oxalate translocation from the soluble pool into the urine is still greater than normal after the liver transplantation while the oxalotic deposits are being mobilized.

been exceptions [33-35]. We have recently reviewed the existing literature and found that of 46 patients (not all of whom were specified as being either type I or type II) reported to have received 55 renal allografts between them, only 20 survived 2 to 5 years, five for 5 to 10 years, and only one patient, who was shown to be pyridoxine responsive, for more than 10 years. This contrasts sharply with the greater than $75 \%$ 1-year survival after renal transplantation for 
other types of chronic renal failure [36]. Morgan et al [37] concluded from their studies of oxalate retention in hyperoxaluric and non-hyperoxaluric renal failure that, in primary hyperoxaluria, plans for renal transplantation should be ready by the time the GFR has decreased to about 20 to 25 $\mathrm{mL} \cdot \mathrm{min}^{-1} \cdot 1.73 \mathrm{~m}^{-2}$, and Watts et al [38] have shown that early renal transplantation, preferably while the patient still has appreciable renal function, plus very vigorous pre- and perioperative hemodialysis to deplete the miscible oxalate metabolic pool, improves graft survival.

To date, our experience has shown us that the main complications after combined liver and kidney transplantation are infections, biliary leaks, and poor function of the grafted kidney, but not irreversible rejection of the grafted liver. The outcome was excellent in Patients 2, 5, and 7, who underwent prompt and vigorous dialysis after the onset of their terminal illness and who received transplants as soon as possible, particularly before there was evidence of gross systemic oxalosis with severe bone disease and/or peripheral vascular insufficiency. The improved outlook for isolated renal grafts in PHI with early transplantation and vigorous perioperative dialysis [38] suggests that similar considerations should apply to the management of patients undergoing either hepatic transplantation or the combined operation. 'The grafted kidney is particularly at risk of damage from the high levels of plasma oxalate, as well as cyclosporine toxicity and immunologic rejection. Very large amounts of calcium oxalate can accumulate in the skeleton, increasing its crystallinity, thereby making it more fragile and producing bone pain. Three of the patients who did poorly (Patients 3,4, and 8 ) because of postoperative renal failure had extensive oxalotic osteodystrophy. Further experience is needed to provide guidelines as to the degree of oxalotic osteodystrophy that should be a contraindication to transplantation. However, the successful outcome to combined hepatorenal transplantation plus intensive perioperative dialysis in a patient with cardiomyopathy and peripheral neuropathy as the systemic manifestations of oxalosis (Patient 6) shows that these patients should be considered for dual organ transplantation. The fact that the plasma oxalate concentration returns to normal before the urinary oxalate excretion (which, however, ultimately normalizes) indicates that oxalotic deposits are mobilized from the tissues when excessive oxalate synthesis is corrected by liver transplantation. It should be noted that the absence of chronic hepatobiliary disease and portal hypertension makes the technical demands of orthotopic liver transplanta- tion less daunting in these patients than in many severely ill patients who require liver transplantation.

It could be argued that a renal allograft should be tried first and combined liver and kidney transplantation reserved until one renal transplantation has been destroyed by calculi and nephrocalcinosis or fails for some other reason. This proposition ignores the morbidity of recurrent stone disease, the risks of urinary tract infections, and, in particular, the risk of progressive potentially irreversible and lethal intrarenal crystallization of calcium oxalate and systemic oxalosis during episodes of obstructive uropathy. Furthermore, since compromised renal function has been assessed as a poor prognostic indicator of outcome in liver transplantation [39], we favor either liver transplantation alone when there is stable and well-preserved renal function or the combined operation with vigorous perioperative hemodialysis as the definitive procedure when the patient is approaching end-stage renal disease. Patients whose GFR is in the range of 25 to 60 $\mathrm{mL} \cdot \mathrm{min}^{-1} \cdot 1.73 \mathrm{~m}^{-2}$ should be followed up closely with sequential assessment based on the rate of stone formation and the rate of loss of overall renal function as judged by serum creatinine and GFR measurements, along with plasma and urinary oxalate levels. The plasma oxalate concentration is a particularly valuable guide with which to assess the imminence of the oxalotic phase of the illness. If the patient is to be treated by elective liver transplantation alone, this should be done as soon as the disease has been shown to be acting aggressively. It should be stressed that renal failure progresses very slowly in some of these individuals, but the terminal phase is characteristically brief. Planning for a combined liver-kidney transplant should begin while the patient still has appreciable renal function (GFR at least 20 to $25 \mathrm{~mL} \cdot \mathrm{min}^{-1} \cdot 1.73 \mathrm{~m}^{-2}$ ). This approách usually means that the liver and kidneys can be obtained from the same donor. However, it is uncertain whether this theoretic advantage is offset by possibly improved kidney graft survival after a twostage procedure in which the metabolic lesion is corrected by liver transplantation, with renal transplantation after a period of vigorous hemodialysis to deplete the oxalate pool. McDonald et al [40] reported the use of a well-functioning renal allograft in a severely oxalotic patient to off-load oxalate and improve the patient's general condition before orthotopic liver transplantation. Given that some oxalate can be removed by very vigorous hemodialysis and the high probability that the renal graft will fail if the excessive oxalate production is not terminated, we do not regard this as the appro- 
priate strategy in most cases. Both extensive oxalotic osteodystrophy with bone pain and prolonged dialysis using conventional regimens worsen the prognosis after liver-kidney transplantation.

It is important to diagnose primary hyperoxaluria early, to explore the possibility of pyridoxine sensitivity, and to institute vigorous medical management and a conservative surgical policy that utilizes modern endoscopic and stone fragmentation techniques fully.

The present studies establish PHI as a member of the group of inborn errors of metabolism in which liver transplantation is recommended to normalize a metabolic pathway and prevent damage to remote organs by a metabolite that accumulates behind a metabolic block in the patient's own, otherwise normal, liver. The patients in this series have all been in end-stage renal failure and hence in need of renal replacement. Most patients with PHI have rapidly progressive urolithiasis, and kidney transplantation could be avoided if the liver was transplanted as soon as the enzymologic diagnosis had been made and it was clear that the patient's disease was following an aggressive clinical course. Alternative strategies, i.e., heterotopic auxiliary liver transplantation and the implantation of hepatocytes, are not considered to be viable alternatives to orthotopic liver transplantation because of competition from the patient's own liver, which functions normally except for the AGT deficiency.

\section{ADDENDUM}

More prolonged follow-up of the surviving patients in this series and of other patients has shown that the urinary oxalate excretion, as well as the plasma oxalate concentration, becomes completely normal after a successful liver graft.

\section{ACKNOWLEDGMENT}

The hepatic enzyme activities were measured by Mrs. P. R. Jennings.

\section{REFERENCES}

1. Archer HE, Dormer AE, Scowen EF, Watts RWE. Primary hyperoxaluria. Lancet $1957 ; 2: 320-2$.

2. Danpure $\mathrm{CJ}$, Jennings $\mathrm{PR}$. Peroxisomal alanine:glyoxylate aminotransferase deficiency in primary hyperoxaluria type I. FEBS Lett 1986; 201: 20-4.

3. Danpure $\mathrm{CJ}$, Jennings PR. Further studies on the activity and subcellular distribution of alanine:glyoxylate aminotransferase in the livers of patients with primary hyperoxaluria type I. Clin Sci 1988; 75: 315-22.

4. Danpure CJ, Jennings PR, Watts RWE. Enzymological diagnosis of primary hyperoxaluria type I by measurement of hepatic alanine:glyoxylate aminotransferase. Lancet 1987; 1: 289-91.

5. Gibbs DA, Watts RWE. The action of pyridoxine in primary hyperoxaluria. Clin Sci 1970; 38: 277-86.

6. Watts RWE, Veall N, Purkiss P, Mansell MA, Hayward EF. The effect of pyridox- ine on oxalate dynamics in three cases of primary hyperoxaluria (with glycolic aciduria). Clin Sci 1985; 69: 87-90.

7. Watts RWE, Calne RY, Williams R, et at. Primary hyperoxaluria (type 1): attempted treatment by combined hepatic and renal transplantation. Q J Med 1985; 57: 697-703.

8. Watts RWE, Calne RY, Rolles K, et al. Successful treatment of primary hyperoxaluria type I by combined hepatic and renal transplantation. Lancet 1987; 2: 474-5.

9. Chalmers RA. The enzymatic spectrophotometric determination of oxalate in blood and urine. In: Rose GA, Robertson WG, Watts RWE, eds. Oxalate in human biochemistry and clinical pathology. London: The Wellcome Foundation, 1979: $61-6$.

10. Kasidas GP, Rose GA. Continuous flow assay for urinary oxalate using immobilised oxalate oxidase. Ann Clin Biochem 1985; 22: 412-9.

11. Kasidas GP, Rose GA. Measurement of plasma oxalate in healthy subjects and in patients with chronic renal failure using immobilised oxalate oxidase. Clin Chim Acta 1986: 154: 49-58.

12. Chalmers RA, Tracey BM, Mistry J, Griffith $K D$, Green A, Winterborn MH. Lglyceric aciduria (primary hyperoxaluria type II) in siblings in two unrelated families. J Inherited Metab Dis 1984; 7 (Suppl 2): 133-4.

13. Wise PJ, Danpure CJ, Jennings PR. Immunological heterogeneity of hepatic alanine:glyoxylate aminotransferase in primary hyperoxaluria type I. FEBS Lett 1987: 222: $17-30$

14. Calne RY. A new technique for biliary drainage in orthotopic liver transplantation utilising the gallbladder as a pedicle graft conduit between the donor and recipient common bile ducts. Ann Surg 1976; 184: 505-9.

15. Calne RY. Recipient operation. In: Calne RY, ed. Liver transplantation, the Cambridge and Kings College Hospital experience. New York: Grune and Stratton, 1983: 155-73.

16. Smith L, Perkins J, Wilson D, McCarthy J, Wiesner R. Biochemical correction ol type I primary hyperoxaluria with combined liver-kidriey transpianll. Kidriey Int 1988; 33: 209.

17. Groth CG, Dubois RG, Corman J, et al. Metabolic effects of hepatic replacement in Wilson's disease. Transplant Proc 1973; 5: 829-33.

18. Kvittingen EA. Hereditary tyrosinaemia type !--an overview. Scand J Clin Lab Invest 1986; 46 (Suppl 184): 27-34.

19. Hood JM, Keop LJ, Peter RF, et al. Liver transplantation for advanced liver disease with $\alpha_{1}$-antitrypsin deficiency. $N$ Engl J Med 1980; 302: 272-5.

20. Starzl TE, Bilheimer DW, Bahnsen $\mathrm{HT}$, et al. Heart-liver transplantation in a patient with familial hypercholesterolaemia. Lancet 1984; 1: 1382-3.

21. Zitelli BJ, Malatak JJ, Gartner JC Jr, Shaw BW, Iwatsuki S, Starzl TE. Orthotopic liver transplantation in children with hepatic based metabolic disease. Transplant Proc 1983; 15: 1284-7.

22. Wolff $H$, Otto $G$, Giest $H$. Liver transplantation in Crigler-Najjar syndrome. A case report. Transplantation 1986; 42: 84

23. Malatak JJ, Finegold $D N$, Iwatsuki $\$$, et al. Liver transplantation for type glycogen storage disease. Lancet 1983; 1: 1073-5

24. Hoeg JM, Starzl TE, Brewer HB. Liver transplantation for treatment of cardiovascular disease: comparison with medication and plasma exchange in homozygous familial hypercholesterolemia. Am J Cardiol 1987; 59: 785-7.

25. Bilheimer DW, Goldstein JL, Grundy SM, Starzl TE, Brown MS. Liver transplantation to provide low-density lipoprotein receptors and lower plasma cholesterol in a child with homozygous familial hypercholesterolaemia. N Engl J Med 1984; 311: 1658-64.

26. Kamoda N, Minatogawa $Y$, Nakamura M, Nakanishi J, Okuno E, Kido R. The organ distribution of human alanine:2-oxogluterate aminotransferase and alanine:glyoxylate aminotransferase. Biochem Med 1980; 23: 25-34.

27. Cochat $P$, Faure JL, Divry $P$, et al. Liver transplantation in primary hyperoxaluria type I. Lancet 1989; 1: 1142-3.

28. Watts RWE, Veall N, Purkiss $P$. Oxalate dynamics and removal rates during haemodialysis and peritoneal dialysis in patients with primary hyperoxaluria and severe renal failure. Clin Sci 1984; 66: 591-7.

29. Klauwers J, Wolff PL, Cohn R. Failure of renal transplantation in primary oxalosis. JAMA 1968: 209: 551.

30. Deodhar SD, Tung KSK, Zulke V, Nakamoto S. Renal transplantation in a patient with primary familial oxalosis. Arch Pathol 1969; 87: 118-24.

31. Chesney RW, Friedman AL, Breed AL, Adams ND, Lemann J. Renal transplantation in primary oxaluria. J Pediatr 1984; 104: 322-3.

32. Vanrentergham $Y$, Vandamme $B$, Lernt $T$, Michielsen $P$. Severe vascular 
complications in oxalosis after successful cadaveric kidney transplantation. Transplantation 1984; 38: 93-5.

33. David DS, Cheigh JS, Stenzel KH, Rubin AL. Successful renal transplantation in a patient with primary hyperoxaluria. Transplant Proc 1983; 15: 2168-71. 34. Whelchel JD, Alison DV, Luke RG, Curtis J, Dietheim AG. Successful rena transplantation in hyperoxaluria. A report of two cases. Transplantation 1983; 35: $161-4$.

35. Scheinman J, Najarian JS, Mauer SM. Successful strategies for renal transplantation in primary oxalosis. Kidney Int 1984; 25 : 804-11.

36. Leading article. Cyclosporin for ever. Lancet 1986; 1: 419-20.

37. Morgan SH, Purkiss P, Watts RWE, Mansell MA. Oxalate dynamics in chronic renal failure. Comparison with normal subjects and patients with primary hyperoxaluria. Nephron 1987; 46: 253-7.
38. Watts RWE, Morgan SH, Purkiss P, Mansell MA, Baker LRI, Brown CB. Timing of renal transplantation in the management of pyridoxine resistant type I primary hyperoxaluria. Transplantaliurı 1988; 45: 1143-4.

39. Cuervas-Mons V. An analysis of the early causes of death in 40 consecutive cases. Hepatology 1986; 6: 495-501.

40. McDonald JC, Landreneau MD, Rohr MS, Devault GA. Reversal by liver transplantation of the complications of primary hyperoxaluria as well as the metabolic defect. N Engl J Med 1989; 321: 1100-3.

41. Watts RWE, Chalmers RA, Gibbs DA, Lawson AM, Purkiss P, Spellacy E. Studies on some possible biochemical treatments of primary hyperoxaluria. Q J Med 1979; 48: 259-72.

42. Watts RWE, Veall N, Purkiss P. Sequential studies of oxalate dynamics in primary hyperoxaluria. Clin Sci 1983; 65: 627-33. 